\title{
Reproductive potential of Chrysoperla externa maintained in different cage sizes in laboratory conditions
}

\author{
Ana Paula Magalhães Borges Battel ${ }^{1}$ Rafael de Andrade Moral $^{1}$ Camila Alves Rodrigues $^{2^{*}}$ \\ Márcio da Silva Araújo² ${ }^{2}$ Wesley Augusto Conde Godoy ${ }^{1}$
}

\footnotetext{
${ }^{1}$ Escola Superior de Agricultura "Luiz de Queiroz", Universidade de São Paulo (USP), Piracicaba, SP, Brasil.

${ }^{2}$ Universidade Estadual de Goiás (UEG), Campus Ipameri, 75780-000, Ipameri, GO, Brasil. E-mail: camilaalvesrodrigues@hotmail.com. ${ }^{*}$ Corresponding author.
}

\begin{abstract}
This study investigated the influence of cage sizes on the survival and reproductive potential of Chrysoperla externa (Hagen). Size of breeding cages significantly affected the reproductive potential of $\boldsymbol{C}$. externa. Our results indicated that in cages smaller (7.5cm of diameter) than those usually recommended for the rearing of this insect (10cm diameter), females showed higher rates of oviposition. Reduction of space for rearing natural enemies in the laboratory is very important for developing biological control programs.

Key words: green lacewing, mass rearing, oviposition, predator.
\end{abstract}

\author{
Potencial reprodutivo de Chrysoperla externa mantidos em diferentes \\ tamanhos de gaiolas, em condições de laboratório
}

\begin{abstract}
RESUMO: Investigou-se a interferência do tamanho das gaiolas de criação de adultos de Chrysoperla externa (Hagen) sobre o seu potencial reprodutivo e sua sobrevivência. O tamanho das gaiolas de criação afetou significativamente o potencial reprodutivo deste crisopídeo. Os resultados indicaram que em gaiolas menores (7,5cm de diâmetro) do que as habitualmente usadas para a criação de adultos desse predador (10cm de diâmetro) ocorreram maiores taxas de oviposição. A redução de espaço para a criação de inimigos naturais para atender aos programas de controle biológico em laboratório é muito importante.

Palavras-chave: crisopídeos, criação massal, oviposição, predador.
\end{abstract}

Biological control depends not only on having efficient natural enemies, but especially on a successful mass-rearing capability, which requires high egg production in a short time period. To guarantee a successful and optimized biological control program, the correct rearing methods must be applied with a low production cost (VAN LENTEREN, 1986).

During the routine mass-rearing procedures, extrinsic and intrinsic factors must be taken into account (CARVALHO \& SOUZA, 2000). Extrinsic factors include quality control, production cost and required materials. General aspects such as diet viability and reproductive potential are intrinsic factors involved in mass rearing (MORELLI et al., 2012). Especially with respect to mass rearing, more attention has recently been given to population density and sex ratio (PESSOA \& FREITAS, 2008). An increase in population density can affect pheromone production, which in turn affects mating and egg production (PARRA, 2002). The sex ratio may also influence the population size (PESSOA \& FREITAS, 2008).

Usually, green lacewings Chrysoperla externa (Hagen, 1861) are reared using cylindrical polyvinyl chloride (PVC) pipes measuring 10, 15 or $20 \mathrm{~cm}$ in diameter, with varying heights (CARVALHO $\&$ SOUZA, 2009). Because of practicality and size, it is common to use cages measuring $10 \mathrm{~cm}$ in diameter. Although this container size is standard, so far no study has compared different container sizes. Success of biological control is ultimately determined by the 
procedure cost and space optimization is essential to increase the production of green lacewings in the laboratory. In this study, we investigated the optimal cage size for $C$. externa.

In our study, adults were collected with an entomological net in the municipality of Jaboticabal, São Paulo State, Brazil. Individuals identified as $\boldsymbol{C}$. externa were allowed to form couples and maintained in PVC cages arranged in a room at $25 \pm 2^{\circ} \mathrm{C}$, photophase of $12 \mathrm{~h}$ and relative humidity of $60 \pm 10 \%$. Larvae were individually reared in vials $4 \mathrm{~cm}$ high and $1 \mathrm{~cm}$ in diameter, since they are cannibals. Eggs of Sitotroga cerealella (Olivier, 1789) were used as food for the green lacewings larvae, following the method developed by FREITAS (2001). Two experiments, (termed phases 1 and 2), were set up on different days to test the influence of cage size on the adult survival. For each experiment, 600 adults obtained from the F2 generation were used. The same population density was used for all cage sizes.

After the adults emerged, five $\boldsymbol{C}$. externa couples were placed in each cage, $23 \mathrm{~cm}$ high and with different diameters: $5 \mathrm{~cm}, 7.5 \mathrm{~cm}$, or $10 \mathrm{~cm}$, for a total of 60 cages, 20 replicates for each cage size. Insects were fed with yeast and honey ad libitum (1:1). Eggs were removed from the cages every two days after oviposition started. They were then transferred to vials $(4 \mathrm{~cm} \times 1 \mathrm{~cm})$ in order to observe egg survival rate, which can be easily determined since they darken as they mature. We observed the number of eggs per cage, hatchability percentage, pre-oviposition period (in days) and the adult survival proportion for 50 days after oviposition.

Hatchability percentage data were analyzed using a quasi-binomial generalized linear model, and male and female survival data were analyzed using a binomial generalized linear model. Total oviposition data were analyzed using quasi-Poisson generalized linear models. Multiple comparisons were made using the confidence intervals for the linear predictors. Data for the pre-oviposition period and mean daily oviposition were analyzed using classical linear models, followed by Tukey tests for multiple comparisons $(\mathrm{P}=0.05)$. When there was a significant interaction between phase and cage diameter, the experiments were analyzed separately; when the interaction was not significant, the data from the two phases were pooled in one analysis for this variable. Goodness-of-fit was assessed using half-normal plots with simulation envelopes (DEMÉTRIO et al., 2014). All analyses were carried out using the R software ( $R$ CORE TEAM, 2016).

\section{Egg hatchability and adult survival}

In our study, cage size did not influence the hatchability percentage or female survival rates (Table 1). Hatchability percentage reached $99 \%$ in all cage sizes. Test for the interaction of phase and cage diameter was significant for male survival $(\chi 2$ $=24.55$, d.f. $=2, \mathrm{P}<0.0001)$ and for female survival showed no significant difference $\left(\chi^{2}=3.63\right.$, d.f. $=2$, $\mathrm{P}=0.1622$ ). Proportion of males surviving was higher in the $5 \mathrm{~cm}$-diameter cage in phase 1 (Table 1). However, for phase 2 the highest survival percentage was reported for the $10 \mathrm{~cm}$-diameter cage (Table 1). This difference in survival rates did not affect the female fertility, since males are able to mate with more than one female (PESSOA \& FREITAS, 2008). Results obtained for egg hatchability were similar to the findings of ZURLINI \& RONBINSON (1980).

\section{Pre-oviposition period}

The test for the interaction of phase and cage diameter showed significance in the result $\left(\mathrm{F}_{2,114}\right.$ $=4.31, \mathrm{P}=0.0156)$. Pre-oviposition period did not differ among the cage sizes in phase 1 , although it was longer for the $7.5 \mathrm{~cm}$ of diameter cage in phase 2 (Table 1). Number of days to sexual maturation of adults was only 1 day longer than in the other cages, and this did not affect the total egg production.

\section{Egg production}

Tests for the interaction of phase and cage diameters showed no significant difference $\left(\mathrm{F}_{2,114}\right.$ $=0.21, \mathrm{P}=0.8093)$. Egg production was higher for the $7.5 \mathrm{~cm}$ of diameter cage (Table 1). Our results showed that the decrease in the cage size from $10 \mathrm{~cm}$ to $7.5 \mathrm{~cm}$ in diameter increased egg production. This improvement could be explained by assuming that under this condition, males and females find each other more easily. In the $5 \mathrm{~cm}$-diameter cage, eggs could be damaged by the stressed movement of individuals in the cage, since this behaviour was observed during the experiment.

Despite the importance of space in rearing insects in the laboratory, this topic has seldom been subject of research, even in other insect groups. For the green lacewing, previous studies have usually assessed the effects of population density on egg production (PESSOA \& FREITAS 2008). We are aware of no other study investigating different cage sizes with $C$. externa.

Influence of cage size on feeding activity has been investigated for other insects, and the results suggest that small cages may decrease feeding behaviour (PHASOMKUSOLSIL et al., 2014). 
Table 1 - Means \pm standard errors for the pre-oviposition period and male survival data for each experiment (phase) and proportion of survival for females and total oviposition data.

\begin{tabular}{|c|c|c|c|c|}
\hline$\varnothing$ of PVC tube $(\mathrm{cm})$ & & 10 & 7.5 & 5.0 \\
\hline \multirow{2}{*}{ Pre-oviposition period (days) } & Phase $1\left(\mathrm{~F}_{2,57}=0.00, \mathrm{P}=1.0000\right)^{(1,2)}$ & $5.00 \pm 0.10 \mathrm{a}$ & $5.00 \pm 0.10 \mathrm{a}$ & $5.00 \pm 0.10 \mathrm{a}$ \\
\hline & Phase $2^{(1)}\left(\mathrm{F}_{2,57}=4.92, \mathrm{P}=0.0107\right)$ & $5.45 \pm 0.35 \mathrm{ab}$ & $6.35 \pm 0.20 \mathrm{a}$ & $5.2 \pm 0.25 \mathrm{~b}$ \\
\hline \multirow{2}{*}{ Male survival (\%) } & Phase $1^{(1)}\left(\chi^{2}=12.07\right.$, d.f. $\left.=2, P=0.0023\right)$ & $34.00 \pm 5.64 \mathrm{~b}$ & $34.00 \pm 5.25 b$ & $55.00 \pm 5.60 \mathrm{a}$ \\
\hline & Phase $2^{(1)}\left(\chi^{2}=15.57\right.$, d.f. $\left.=2, P=0.0004\right)$ & $55.00 \pm 5.60 \mathrm{a}$ & $38.00 \pm 5.41 \mathrm{ab}$ & $28.00 \pm 5.31 \mathrm{~b}$ \\
\hline Female survival (\%) ${ }^{(1)}$ & $\left(\chi^{2}=0.41\right.$, d.f. $\left.=2, P=0.8154\right)$ & $72.50 \pm 3.18 \mathrm{a}$ & $72.50 \pm 3.70 \mathrm{a}$ & $70.00 \pm 3.79 \mathrm{a}$ \\
\hline Total oviposition $^{(1)}$ & $\left(\mathrm{F}_{2,117}=5.47, \mathrm{P}=0.0054\right)$ & $2271.95 \pm 77.00 \mathrm{ab}$ & $2547.10 \pm 81.54 a$ & $2150.45 \pm 97.77 b$ \\
\hline
\end{tabular}

${ }^{(1)}$ Means followed by the same letter in line are not statistically different $(\mathrm{P}=0.05) .{ }^{(2)}$ As the variances of the three treatments were equal, the treatment sum of squares was zero and consequently the F statistic was equal to zero as well.

Suitable space has been considered an important in rearing beneficial insects, mainly when the purpose is to establish a mass-rearing routine (VAN ERENS et al., 2012). Our results showed that is possible to improve mass rearing by using more cages and producing more eggs.

\section{ACKNOWLEDGEMENTS}

We are grateful to Sergio de Freitas (in memoriam) for the support given during this research. We would like to thank Conselho Nacional de Desenvolvimento Científico e Tecnológico $(\mathrm{CNPq})$ and Fundação de Amparo à Pesquisa do Estado de São Paulo (FAPESP) for research fellowships.

\section{REFERENCES}

CARVALHO, C.F.; SOUZA, B. Métodos de criação e produção de crisopídeos. In: BUENO, V.H.P. Controle biológico de pragas: produção massal e controle de qualidade. Lavras: UFLA, 2009. p.77-115.

DEMETRIO, C.G.B. et al. Models for overdispersed data in entomology. In: FERREIRA, C.P.; GODOY, W.A.C. Ecological modelling applied to entomolomology. New York: Springer, 2014. p.219-259

FREITAS, S. Criação de crisopídeo (bicho lixeiro) em laboratório. Jaboticabal: Funep, 2001. 20p.

MORELLI, R. et al. New protein sources in adults diet for mass-rearing of Anastrepha fraterculus (Diptera:Tephritidae). Brazilian Archives of Biology and Technology, v.55, n.6, p.827833, 2012. Available from: <http://dx.doi.org/10.1590/S1516-
89132012000600004>. Accessed: Nov. 08, 2016. doi: 10.1590/ S1516-89132012000600004.

PARRA, J.R.P. Criação massal de inimigos naturais. In: PARRA, J.R.P. et al. Controle biológico no Brasil: parasitóides e predadores. São Paulo: Manole, 2002. p.143-164.

PESSOA, L.G.A.; FREITAS, S. Reproductive capacity of Chrysoperla externa (Hagen) (Neuroptera, Chrysopidae) in function of the number of individuals per unit of rearing. Revista Brasileira de Entomologia, v.52, n.3, p.463-466, 2008. Available from: $\quad<$ http://dx.doi.org/10.1590/S0085-56262008000300022>. Accessed: Nov. 08, 2016. doi: 10.1590/S0085-56262008000300022.

PHASOMKUSOLSIL, S. et al. Factors influencing the feeding response of laboratory-reared Aedes aegypti Southeast Asian Journal of Tropical Medicine and Public Health, v.45, n.1, p. 40-46, 2014.

R CORE TEAM. A language and environment for statistical computing. Viena: R Foundation for Statistical Computing, 2016. Available from: <http://www.R-project.org/>. Accessed: Nov. 08, 2016

VAN ERENS, E.S. et al. A bug's life: large-scale insect rearing in relation to animal welfare. Venik: Wageningen, 2012. 57p.

VAN LENTEREN, J.C. Parasitoids in the greenhouse: successes with seasonal inoculative release system. In: WAAGE, J.K.; GREATHEAD, D.J. Insect parasitoids. New York: Academic, 1986. p.341-374.

ZURLINI, G.; ROBINSON, A.S. The effect of crowding on adult populations of (Delia $=$ Hylemya $)$ antiqua (Meigen). Researches on Population Ecolology, v.22, p.228-241, 1980. Available from: $<$ http://dx.doi.org/doi:10.1007/BF02530847>. Accessed: Nov. 08 2016. doi: 10.1007/BF02530847. 